\title{
Ngā Tuakiri o te Tangata: Being Māori in Early Childhood Education
}

\author{
Lesley Rameka \\ Faculty of Education, Waikato University, Hillcrest Rd, Hamilton East Hamilton, Hamilton, 3240, New Zealand
}

\begin{abstract}
Before the arrival of Europeans in Aotearoa, New Zealand and their subsequent settlement in the 1800s, there was no concept of a Māori identity. Over time, however, as a result of rapid colonisation, Māori became a minority population in New Zealand. Consequently, the term Māori as normal or usual, began to lose its meaning (Webber, 2008), and another meaning began to emerge based on contrasts with the Pākehā settler population. This paper explores the complex and increasingly diverse nature of Māori identities in contemporary Aotearoa/New Zealand, including contemporary early childhood contexts. It discusses the importance of negotiating the terrains of cultural knowledge, values and understandings in order to define what 'being Māori' means for teachers and children in an increasingly diverse and complex settings.
\end{abstract}

- Keywords: Māori identities, early childhood, education

Before the arrival of Europeans to Aotearoa, New Zealand, there was no concept of a Māori identity. Māori had no name for themselves except in terms of tribal connections (Maaka \& Fleras, 2005). The term 'Māori' as an identifier of a person developed in relation to the arrival of Pākehā (New Zealanders of British Descent), and only came into existence within that specific relationship. The word 'Māori' merely meant normal or ordinary as opposed to the Pākehā settlers who were viewed as different (Durie, 1998; Webber, 2008). Identity was defined in terms of social, geographic and historical factors. Durie (1998, p. 53) explains that 'The original inhabitants of New Zealand did not refer to themselves as Māori; rather they were Rangitāne or Ngāti Apa or Tūhoe or any of the forty or more tribes'.

Over a relatively short period of time, however, as a result of rapid colonisation, the Māori population plummeted from an estimated 100,000-120,000 in 1800 to less than 60,000 in 1858, and 42,000 in 1896 (Te Ara - The Encyclopedia of New Zealand). Māori effectively became a minority population in New Zealand, accounting for only $14 \%$ of the total population by 1874 (Durie, 1998). Consequently, the term Māori as normal or usual, began to lose its meaning (Webber, 2008), and another meaning began to emerge also based on contrasts with the Pākehā settler population. The stark cultural differences with the settlers served to emphasise the commonalities of Māori rather than tribal differences and aided the creation of a generic Māori identity. However, this identity was only really obvious to the settlers and was largely determined by them as opposed to a reflection of Māori homogeneity. It was a process where new myths were developed and a new version of Māori identity was forged. Māori, however, 'were not entirely convinced that they were the different ones; they were perplexed enough trying to understand the peculiarities of western ways and did not think it necessary to try and decipher their own "normal" culture' (Durie, 1998, p. 54).

This paper explores the complex and increasingly diverse nature of Māori identities in contemporary Aotearoa/New Zealand, and the importance of reclaiming and reframing Māori identities within contemporary early childhood contexts. First, Māori interpretative systems and the impact of colonisation and urbanisation on Māori identity is discussed. The factors that brought about a Māori cultural renaissance and a reclaiming of Māori perceptions of identity in contemporary contexts is then considered. Next, an overview of the research study Te Whatu Kākahu - Assessment in Kaupapa (Philosophy) Māori Early Childhood Practice (Rameka, 2012) is discussed and understandings of Māori identities that emerged from the research is explored.

ADDRESS FOR CORRESPONDENCE: Lesley Rameka, Faculty of Education, University of Waikato, Private Bag 3105, Hamilton 3240, New Zealand. Email: lrameka@waikato.ac.nz. 


\section{Māori Interpretative Systems}

Gee (2000) asserts that fundamental to any interpretation of identity are interpretative systems and it is not possible to have an identity of any kind without an interpretative system underpinning the recognition of that identity. He states that

The interpretive system may be people's historically and culturally different views of nature; it may be the norms, traditions, and rules of institutions; it may be the discourse and dialogue of others; or it may be the workings of affinity groups. What is important about identity is that almost any identity trait can be understood in terms of any of these different interpretive systems. (p. 108)

Māori identity can be viewed through a number of interpretative systems. These interpretative systems are not distinct or separate from each other, but rather are interrelated components of a dynamic weaving that encompasses Māori identities both historical and contemporary. These interpretative systems include: whakapapa, whānau/hapü/iwi, whenua and te reo.

\section{Whakapapa}

Whakapapa denotes the genealogical descent of Māori from the divine creation of the universe to the living world, from the past to the present time (Berryman, 2008). Māori are descendents of the heavens and through whakapapa can trace lineage back to the very beginning of time and the creation of the universe (Te Rito, 2007). Whitt, Roberts, Norman and Grieves (2003) add that the importance of whakapapa within Māori culture cannot be overestimated in that it is a fundamental form of knowing and acts as a template for the ways the world is viewed. Furthermore, the literal translation of whakapapa is to 'place in layers', so there are multiple layers and interpretations that form the basis of Māori values and beliefs (Cheung, 2008; Te Rito, 2007; Walker, 1993). Whakapapa, therefore is fundamental to Māori understandings and is at the very core of what it means to be Māori (Barlow, 1991; Berryman, 2008; Cheung, 2008; Rangihau, 1975). It is 'firmly embedded in the Māori psyche' (Te Rito, 2007, p. 4). 'Māori conceive of personal identity in terms of whakapapa or genealogy - it is your whakapapa that makes you who you are, literally' (Patterson, 1992, p. 157).

\section{Whānau/Hapū/lwi}

Māori society is traditionally organised and identity expressed in terms of kin-based descent groupings. Identity formation and maintenance within these contexts is a fairly straightforward exercise, founded on kinship, and living in a community. There are three main kinship classifications in traditional Māori society. The first is whānau, the basic unit of Māori society. Whānau is commonly understood to mean; family. Whānau can be translated as 'to give birth' and is the family grouping of Māori society.
It functions as the social and economic unit of day-to-day living and activities. The second is hapū, the sociopolitical unit within Māori society, consisting of groups of related whānau. Hapū are marked by autonomy in the management of affairs, and being both independent and interdependent on the complex web of kin networks for its operation. Iwi is the last classification. Iwi is commonly understood to mean; tribe. They are the largest political and economic units in Māori society. They are independent units that occupied tribal lands, and defended their lands and political integrity against others. Iwi refers to related hapū who could trace descent from a single ancestor or from their bones. These social groupings are not completely discrete, with size and function varying in different locations (Barcham, 1998; Hohepa, 1978; Rangihau, 1975).

\section{Whenua}

Whenua or land is fundamental to a Māori identity. The term whenua is also used for the placenta. This is important because for Māori, the placenta is buried in the land, in a place of significance, and at death, the body is buried in the land, also in a place of significance, thus completing the cycle and completing the symbolic and physical connection to the land. This also provides the basis for the term, tangata whenua, or people of the land (Williams, 2004).

It is to do with that sense of being essentially at one with nature and our environment, rather than at odds with it. As tangata whenua we are people of the land - who have grown out of the land, Papatūannuku, our Earth Mother. Having knowledge of whakapapa helps ground us to the earth. We have a sense of belonging here, a sense of purpose, a raison d'etre which extends beyond the sense of merely existing on this planet. (Te Rito, 2007, p. 4)

\section{Te Reo}

The Māori language, te reo is regarded as sacred as it was given to the ancestors by the gods and so it is a means to know the gods (Barlow, 1991). It has a life force, a living vitality and a spirit. Love (2004) adds that te reo Māori is an aspect of wairua (spirituality) which stems from and is integral to the spiritual realm. It is both a communication tool and a transmitter of customs, valued beliefs, knowledge and skills from one person to the next, from one generation to the next. It reflects the cultural environment and ways of viewing the world. It is a source of power, a vehicle for expressing identity (Barlow, 1991). According to Reedy (2003), language is the window into any culture, as it conveys the values and beliefs of its people.

\section{The Impact of Colonisation and Urbanisation}

As previously stated, the Māori identity that began to emerge in the 19th century was more a result of colonisation than a developing sense of Māori nationalism. This 
identity was further shaped after World War Two with the alienation of Māori from tribal lands, because of government land purchasing policies including the Māori Land Court abolitions of individual title, and Crown land purchases and confiscations (Boyes, 2006). Alienation from land had a devastating effect on Māori identity, personal, social and spiritual. It severed the physical and spiritual bond with the land, and with past generations who had lived on the land thus alienating Māori from a fundamental source of identity, of 'being Mãori'. With the loss of land, came the loss of the community's economic base, culminating in large numbers of Māori needing to move to urban environments to find employment. Over $80 \%$ of the Māori population moved from tribal areas to the cities and towns (Durie, 1998; Raerino, 2007). Walker (1989) argues that for $70 \%$ of urban Māori, all ties to the land were lost completely.

After the 1970s, few Māori were able to live in extended family environments, with the vast majority living in urban nuclear families - a family structure alien to most. Furthermore, living in urban communities meant that it was not possible to actively participate in and contribute to the day-to-day business of the kin group. This dislocation from tribal influences and connectedness resulted in a new cultural identity being developed, one based simply on being Māori rather than being tribal. This shift from the tribe being the main source of identity to but one component of being Māori was critical movement in the development of contemporary Māori identities (Maaka \& Fleras, 2005). Māori identity, therefore, underwent major changes as a result of colonisation and urbanisation, with significant numbers of Māori neither being able to fully connect to their tribal roots nor able to integrate into the mainstream of wider Pākehā-led society (Durie, 1998; Maaka \& Fleras, 2005; Raerino, 2007). McIntosh (2005) describes it as follows:

In this sense, urban defranchised Māori who have no knowledge of their whakapapa may find themselves culturally homeless, a potent element of a sensed alienation from both Māori and non-Māori society. For many, homelessness begins as a symbolic state and transforms into an actual state. (p. 42)

Alienation from the Māori language added to this sense of homelessness. In 1900, the Māori language was banned in schools, which led to generations of Māori children being deprived of a fundamental aspect of their identity. The decline in speakers of the Māori language was marked, and by the 1970s, there was a danger that the language would become extinct. Maaka and Fleras (2005) emphasise that urbanisation, coupled with exposure to English-language media, has generated identity problems for Māori youth, who are 'caught between cultures desiring the two, comfortable with neither and rejected by both' (p. 70). This has led to many Māori living at the margins of both Māori and mainstream societies.
McIntosh (2005) adds that for many, exclusion or marginality is the norm, with disadvantage experienced from birth. This continues to be reflected in negative Māori educational, health, employment and justice statistics (Marriot \& Sim, 2014) whose study suggests worsening outcomes for Māori people in the form of increasing gaps in negative social indicators when compared to the Pākehā population.

\section{Reclaiming Māori Identities}

\section{Māori Renaissance}

The validity of a universal Māori identity began to be questioned when the realities of urbanisation and detribalisation became evident in the last third of the 20th century (Durie, 1998). Even with huge social and economic upheavals, Māori did not completely discard being Māori and being tribal. For some, the absence of traditional tribal connections led to them creating their own urban social networks and new forms of social institutions, including pan-tribal voluntary associations, church groups, clubs, youth groups and urban marae. These institutions provided a connection between the urban context in which they lived and their attachments from the past. As Barcham (1998) explains, although urban Māori may have lost some of the symbols that were used to demarcate their ethnic and cultural identity in the tribal environment, other symbols have been adapted to support a coherent life in the modern urban context.

In the 1970s and 1980s, influenced by the politics of indigeneity and encouraged by government policy on tribal management, there was a reaffirmation of tribal identity by many Māori in preference to a generic Māori identity (Durie, 1998). The result of this retribalisation and resurgence of tribal pride was a substantial growth in the numbers of Māori who claimed affiliation to tribal groups. Barcham (1998) adds that what occurred was a polarisation of Māori society, with those who viewed territorial and tribal affiliation as the only authentic institutional foundations for identity on one side, and those that argued for a more inclusive and increasingly detribalised identity that encompassed multiple realities and modern contexts on the other (Maaka \& Fleras, 2005).

Colonisation, assimilation, land loss, language loss and urbanisation therefore have worked to transform concepts of Māori identity. This has created a challenge for Māori, about how to maintain a cultural identity within a constantly changing contemporary environment. Māori identity is marked by multiple sites of belonging and identity. Identifying as Māori for many is related to choice, rather than traditional customs, laws and structures. It must be recognised that some Māori choose not to identify as Mãori due to negative perceptions associated with being Māori; however, the huge majority of Māori still choose a Māori identity. Put succinctly, 'a Māori is a Māori until 
they reject being Māori or Māori things' (Raerino, 2007, p. 30).

\section{Contemporary Māori Identities}

A further complexity related to contemporary Māori identities is that living in the modern world requires that Māori develop the ability to operate successfully across two separate cultures, the Pākehā and the Māori, to become effectively bicultural (Durie, 1997). While this does not necessarily result in cultural schizophrenia, it does require extra fortitude in the development of strong personal and social identity (Durie, 1997). Māori are required to negotiate radically different cultural terrains of assumptions, behaviours, values and beliefs about how the world is constituted, and ways of acting and being within the world; however, this expectation to live and walk in two worlds is not extended to Pākehā. Berryman (2008) makes the point that being able to live one's own culture when everyone around you is living another's is a challenge. Identity formation for many urban Māori is now conceived in a symbolic as well as a physical way. For Māori who have been alienated from tribal and cultural roots, gaining knowledge of whakapapa and reclaiming one's tribal identity offers freedom to choose and develop identity on an intellectual, political and spiritual level. This supports the development and retention of a sense of connectedness to people, place and the wider physical and spiritual worlds, no matter where the individual resides (Durie, 1997; Raerino, 2007). The challenge therefore is to construct an 'inclusive supra-Māori identity' that does not exclude either tribal identities or pan-tribal Māori identities, but simultaneously recognises and accommodates the multiple realities that exist within modern settings (Maaka \& Fleras, 2005, p. 66).

Contemporary Māori identity is one of both unity and diversity: on some levels, Māori are unified; on others divided by their distinctiveness (Maaka \& Fleras, 2005). Māori are not a homogeneous group and there is no one single Māori cultural stereotype. Being Māori has different meanings for different groups and 'Māori are as diverse as any other people - not only in socio-economic terms but also in fundamental attitudes to identity'. (Durie, 1998, p. 59)

Reclaiming one's identity, or becoming the person one has always been, not only takes time but is often a process of searching, learning and unlearning (Parker, 2000). Reclaiming one's identity is a process of personal and cultural transformation that requires the unmasking of identities that are not one's own. Unmasking identities inherited as a legacy of domination and oppression such as slavery and colonisation are part of this process of developing a positive cultural identity. Tisdell $(2001$, p.147) states that key to this unlearning is learning one's own history from the perspective of members of one's own culture. In this way, it is possible to reclaim what had previously been lost or unknown to them, and reframe in a more positive way what had earlier been seen sometimes subconsciously as a negative.

Learning and identity are inherently linked. 'Learning implies becoming a different person (and) involves the construction of identity' (Lave \& Wenger, 1991, p.53). Geijsel and Meijers (2005) add that identity can be viewed as 'the ever-changing configuration of interpretations that individuals attach to themselves, as related to the activities they participate in'. In other words, identity is constructed through the use of 'culturally available building materials' (p. 423). Early childhood teachers therefore have a responsibility to ensure that Māori children have access to the building materials, and learning activities that support pride in and connectedness with 'being Māori'. This pride in and connectedness with 'being Māori' has not been a feature of past early childhood experiences for Māori children.

\section{Māori Identities and Māori Education}

The history of schooling for Māori has been one of cultural dislocation, deprivation and subjugation. The missionaries believed Māori lived in a state of 'barbarism', with inferior intellect, language and culture, thus in order to save their souls, Māori needed to be civilised and Europeanised (Belich, 2001; Hokowhitu, 2004; May, 2003a; 2005). The aim of the early mission schools was to interrupt the transmission of Māori culture, language and world-views and replace them with what was perceived as the far superior and civilised European ones, and to transform Māori into 'Brown Britons' (Belich, 2001). The Māori child was therefore viewed as outside the norms of development and in need of remediation The early European-style infant schools in New Zealand aimed to save children from the 'deprivation' of their home environments and to 'civilise' them (May, Kaur, \& Prochner, 2006).

Prior to the 1960s, there was little involvement of Māori children and families in early childhood services. The migration of Māori families from the rural tribal areas to urban environments in the 1940s and 1950s raised issues for both primary and early childhood education. Urban teachers were unprepared for the influx of Māori children, and often identified them as failures, lacking the basic experiences of Pākehā children (May, 2005). Early childhood education was seen by policy-makers as a means of compensating for the cultural deficits of the Māori home (Pihama, 1996).

By the late 1980s and 1990s, the raised consciousness among Māori communities facilitated a Māori revitalisation movement which focussed on Māori language, cultural philosophies, preferences, aspirations and practices (Bishop, 2005; Bishop \& Glynn, 1999; Mahuika, 2008). Māori rejected the deficit focus present in previous educational initiatives and policies, and stressed Māori autonomy. 'Kaupapa (Philosophy) Māori responded to the dual 
challenge of imminent Māori language death and consequent cultural demise, together with the failure of a succession of government policy initiatives' (Bishop \& Glynn, 1999, p. 62). The Kaupapa Māori approach developed across all education fields including Te Kōhanga Reo (ECE), Kura Kaupapa Māori (Primary), Wharekura (Secondary) and Wānanga (Tertiary) (Bishop \& Glynn, 1999). Te Kōhanga Reo, or Māori language nests, were established as a strategy for nurturing and revitalising the Māori language, culture and traditions and enhancing life opportunities, access to power and equality of opportunity (Bishop, 1998; Consedine \& Consedine, 2005; Irwin, 1990; Mutu, 1998; Pihama, Smith, Taki, \& Lee, 2004).

\section{Contemporary Early Childhood}

Te Whāriki is the New Zealand Ministry of Education's early childhood curriculum policy statement. Te Whāriki: He Whāriki Matauranga mo ngā Mokopuna o Aotearoa/Early Childhood Curriculum (Ministry of Education, 1996) is a bicultural, socioculturally conceived curriculum document, partially written in Māori. Te Whāriki translates to 'a woven mat' that allows for diverse patterning depending on knowledge bases, beliefs and values which all may stand upon. Accordingly, '... the whāriki concept recognises the diversity of early childhood education in New Zealand. Different programmes, philosophies, structures and environments will contribute to the distinctive patterns of the whāriki' (p. 11). Te Whāriki is an example of how traditional Māori and Pakeha values, concepts, worldviews and philosophies have been integrated into a modern, bicultural, educational document. Māori perspectives and world-views are integral to the curriculum document. Te Whāriki makes a number of statements that reflect the bicultural intention of the document including:

New Zealand is the home of the Māori language and culture: curriculum in early childhood settings should promote te reo and ngā tikanga Māori, making them visible and affirming their value for children from all cultural backgrounds. (p. 42)

Adults working in the early childhood education setting should recognise the significance of whakakpapa, understand and respect the process of working as a whānau, and demonstrate respect for Māori elders. (p. 64)

There should be a recognition of Māori ways of knowing and making sense of the world and of respecting and appreciating the natural environment. (p. 82)

Te Whārik therefore incorporates responsibilities for all early childhood teachers to integrate Māori values, perspectives and language into their programmes and practices. The effectiveness of this integration is however mixed. A 2010 Education Review Office (ERO) report, Success for Māori Children in Early Childhood Services, which evaluated the provision of education and care for
Māori children in 576 early childhood services reported that many early childhood services:

- stated that they 'treated all children the same' and lacked strategies that focussed on Māori children as learners;

- included statements about values, beliefs and intentions in centre documentation that were not evident in practice;

- did not use effective processes to find out about the aspirations of parents and whānau of Māori children; and

- lacked adequate self-review processes to evaluate the effectiveness of their provision for Māori children (Education Review Office, 2010, p. 1).

Webber, (1996) points out that there are two types of Māori education. The first is education for students who identify as Māori or education for Māori, which focusses on Māori learners. The second is education for all students about Māori, and emphasises knowledge about Māori, tikanga Māori, information systems and learning basic language. The huge majority of the 25,284 teaching staff in early childhood (MoE, 2014), both Māori and non- Māori are graduates of Initial Teacher Education (ITE) institutions, where Maori education is about, rather than for Māori. Hunt and Macfarlane (2011) make the point that for Māori students and teachers, this is akin to living in two worlds, acting rather than participating in the teaching and learning process. It also brings to the fore a primordial perspective of ethnicity and identity, based on inherited, fixed homogeneous categories of identity (May, 2003b). Of the 19 early childhood ITE providers (MoE, 2015), two are distinctively Māori institutions, Te Wānanga o Raukawa, and Te Whare Wānanga o Awanuiārangi. Both have overarching philosophies, pedagogies and values that are embedded within Māori worldviews, and aim to support Māori learners to achieve and succeed as Māori. Within these institutions, the heterogeneous nature of Māori identities and histories are recognised and 'being Māori' in it's many forms is discussed, affirmed and acknowledged. Māori students within other institutions, where Māori is viewed as a content area, very rarely have the opportunity to develop understandings of what it means to 'be Māori' in educational contexts including early childhood education.

In the next section, understandings of contemporary Māori identities that emerged from the Te Whatu Kākahu - Assessment in (Philosophy) Kaupapa Mãori Early Childhood Practice (Rameka, 2012) study which illustrates the reclaiming and reframing process above will be described.

\section{The Research}

The study followed the journeys of three Māori early childhood services and kōhanga reo (immersion language nests) in the development of Kaupapa (philosophical) Māori early childhood assessment understandings and 
framings. Central to the research was the articulation of Māori values, understandings and epistemologies within early childhood education teaching, learning and assessment theory and practice. Each case study service worked on developing understandings of Māori ways of knowing and being identifiable within their particular early childhood and community context; and how these understandings could be meaningfully reflected in assessment thinking and practice.

A qualitative, Kaupapa Māori research methodology was used to gather, collate and analyse data in the study. It utilised an emergent design and mixed-method approach to the data collection and analysis. It built on Māori philosophical and epistemological understandings that expressed Māori ways of knowing and being. The study aimed to make a change for Māori children and families by challenging, critiquing and transforming dominant educational perceptions such as views of the Māori child, the nature of learning, pedagogy and culturally valued learning.

The case study services engaged with, endeavoured to make sense of, critiqued, questioned, looked for fit, resisted and transformed perceptions related to Te Akoranga [Māori Schooling]; Ngā Tuakiri o te Tangata [Māori Identities]; Te Āhua o te Mokopuna [The Image of the Child] and Aromatawai [Assessment]. Each service's context was unique as was their journey, emergent understandings, practices and assessment.

\section{Reclaiming and Reframing Being Māori in Early Childhood Education}

One of the important steps in reclaiming and reframing Māori identities, was unlearning the learning that had previously not been thought about in the early childhood services (Tisdell, 2001). Being Māori was not something teachers had explored previously; and was often a 'taken for granted', just 'what people did'. It was related to individual teacher's upbringings, experiences and backgrounds, including; knowledge of whakapapa, iwi/hapū/whānau and whenua connectedness, understandings and experiences of the Māori world, te reo abilities; and comfort with being and reflecting Māori identities in a modern urban environment. The process was one of negotiating cultural terrains including ways of feeling, being and acting in in early childhood services.

And often you do it... because that's how it feels right to do it, but [Māori educators]very rarely get the chance to actually analyse what it is that makes you do it that way... you actually had to stop and think why... then realising it's because it's Māori (Research Notes, Case Study Two).

Explicating Māori early childhood practices from generic early childhood practices was not a straightforward process due to the need to unlearn what had previously been a given, such as teacher training, and early childhood assumptions around what it meant to be a teacher. This required unmasking some identities and reclaiming others. It involved an in-depth analysis of what made the services Māori, what made them different to mainstream early childhood services and how these differences were reflected in the service. Hera (Case Study Two Supervisor) explained that identifying specific Māori values, perceptions and practices in early childhood required a Māori 'heart', which she related to understandings of 'being Māori'. One discussion comparing two teachers, one trained with a great deal of experience in early childhood, and the other untrained but with a strong Māori background, highlighted essential differences in perceptions and ideas of valued knowledge.

She [teacher 1] was trained and she was academically inclined but [with] not enough [heart]. It was a Māori heart. What she [teacher 2] was seeing and how she was saying it was very Māori, full of heart.

In the initial stages of the study, teachers focussed on raising awareness and articulating what they did that was specifically Māori, that expressed and reflected 'being Māori' and reviewing why these practices, routines and understandings were important to 'being Māori'. Ruth (Case Study One Supervisor) explained it was about reviewing what they were already doing and asking themselves probing questions such as:

What made us unique from other services? What strategies did we have in place? What types of assessments did we use? What was the basis of our framework? My gosh what did we do?

The review also included analysing the types and frequency of Māori activities being provided in the service. This was key to critically reflecting on what 'being Māori' entailed in the service. Questions were asked about everyday events such as karakia (prayer) and mihimihi (formal greetings). What was the rationale for these activities? Why were they important? What does it mean? Who is it for? Who benefits? Are they relevant today? From the review, the teachers realised that what they saw as normal practice was not necessarily normal for other services. This involved indentifying Māori identities within the multiple sites of identity and belonging.

So it was about trying to find out what is special to just us and what is normal to everyone else... what is different and probably what defines us as the service that we are ... made us look at what we took for granted ... and say 'this is why we are special' and 'this is why we are what we are' (Ruth).

Through this process, the teachers began to recognise that being Māori meant they viewed things from Māori interpretative lenses and this was reflected in practice. It relates to what Parker (2000) refers to as 'becoming who they have always been' and 'unmasking themselves'. This was a very powerful revelation.

For us it meant that ... if we were to walk into another childcare service, how they did things was different to how 
we did things. We thought that we were the same as everybody else... our practices were different ... we realised our practice was part of who we were, or who we are... it's part of us or part of our culture... And so it refined some of our practices ... with a bit more purpose... We looked at ourselves and said, 'Okay, we're Māori, how do we use this for us as Māori ... a tool for us?' (Hera).

Viewing learning through a Māori interpretative lens required a positioning of both historical and contemporary Māori ways of knowing and being within learning. Refocussing or reclaiming Māori ways of viewing and reflecting development was a key to the development of what Maaka and Fleras (2005, p. 66) called an 'inclusive supra-Māori identity'.

I think what it is ... is that you don't have to be a Pākehā, you can ... celebrate being Māori, and you can do it the way you believe it to be done. And you've got the liberty ... and the freedom to do it then you do it (Hera).

In order to utilise a Māori interpretative framing teachers needed to critique their own, sometimes hegemonic, perceptions and assumptions about children. It also required refocussing on the service philosophy, questioning whether their practice was aligned with their philosophy, and how did they know? Teachers commented that:

For me, what it says is that you have to look at ... through Māori ... you have to see it through Māori eyes in order to understand (Ruth).

It challenged us to see things through a Māori vision. (Research Notes, Case Study Two).

The following section outlines one service's development of processes and protocols that reflected Māori early childhood practice.

\section{Freedom and a Celebration of 'Being Māori'}

The service developed a more planned, focussed process for the implementation of Māori culture into the programme. Mat times became more structured with Māori protocols being developed and implemented. Mihimihi (traditional introductions) were introduced which required that children learn their genealogy and be able to recite it to the group. This focus then began to flow from mat time into other areas such as the development of whanaungatanga (relationship) links to whanau (extended family), school and the community, including the marae (traditional meeting place). The result of the work was the development of a 'transition to school' ritual, involving the handing over of the taonga (gift), the child. Leading up to the transition (to school) ceremony, the children learned the appropriate processes including pōwhiri (welcome ceremony), karanga(traditional call), korero (speeches), waiata (songs), harirū (hand shaking), kai (food) and whakangahau (entertainment). Children also learned their specific roles within these processes including: kaikaranga (caller), kaikōrero (speaker) and kaiwero (challenger).

After much discussion and brainstorming the staff collectively came up with a wonderful idea of 'Te Huarahi (The Journey)'. It was decided that a special transition ceremony would be held for the five year olds who were enrolled at the kura (school). A special pōwhiri (welcome ceremony) would be arranged at the school and consultation with the parents and whannau of the child making the transition. This would encourage whānau participation, a smoother transition from service to kura and it would also be a wonderful way for the service staff to pass over the taonga who they have invested much love and time into (Hera).

An unforeseen, but hugely beneficial outcome of the focus on Māori activities was that children and whānau were able to engage, in a small, but safe way, with their cultural identity. As previously stated (Durie, 1998; Maaka \& Fleras, 2005; Raerino, 2007), large numbers of urban Māori struggle to make meaningful links to their culture, language and identity as a result of colonisation and urbanisation, and participation in the services activities supported the reconnection and reclamation of their identity and culture. Hera describes the 'handing over' day for one particular child ' $\mathrm{C}$ '.

The participation of the service, C's whānau (family), the kura(primary school) and other whānau made the day of whakawhanaungatanga (relationship building). It was a great time of celebration by all who attended. The transition to school was made smooth with the full participation of the kura students from the time of the wero(traditional challenge) to the hākari(feast). It was a time of great unity for all who attended.

This event is an example of whānau being intimately involved in the service activities, along with the primary school and church community. This 'handing over the taonga' (child) to the primary school was a community event that involved the child's whānau, the service and school whānau and the church community. This resulted in the development of stronger relationships between whānau, community and the service.

Deepening understandings of tikanga (customary system of values and behaviours) Māori, te reo, appropriate behaviours in different situations, sequencing of ceremonial practices For those community and whānau members who are not familiar with Māori protocols the transitioning ceremony is a way of deepening understandings (Research Notes Case Study Two).

The transition process not only provided learning opportunities for children and teachers in the service but also for whānau and community. Whānau were able to deepen their understandings of tikanga Māori and te reo alongside their children. It provided a safe and welcoming environment for whānau and community to be involved in a process that they may not ordinarily be involved with. Some of the families had little connection with te 
Ao Māori. Research Notes highlight the changing urban Māori reality.

We discussed the changing Māori reality, i.e. children who have no knowledge of the sea and kaimoana, who have never been to collect sea food or traditional Māori food, children who have no links to traditional homes, foods, marae etc (Research Notes, Case Study Two).

\section{Being Māori Differently}

Being situated in an urban areas meant that the services were often not able to access nor were they bound by tribal expectations and norms, a situation May (2003a) describes as the 'primordial/situational dichotomy of ethnicity'. The tensions between these two positions were resolved for the service when Hera realised that the services needed to utilise whatever resources they had at hand to support their development, whether this fitted with traditional views or not.

I think ... that was realised when we went to that meeting, and the thing about ... 'Oh no, we wouldn't let the little girls do the karanga (traditional call) or 'We wouldn't let the boys do the mihimihi' (greeting) ... and I thought, 'Well, we can't limit that' ... because we don't have many speakers and we don't have many kuia (female elder) out there ... These whanau (extended families) are urban Māori ... they don't have the marae (traditional meeting places) so it was like we had the freedom to do it (Hera).

While the service did not exclude tribal identities, it recognised the multiple realities that exist within modern contexts (Maaka \& Fleras, 2005). This freedom provided a sense of comfort and ease with who they were and what they were trying to achieve. It allowed them to develop their own understandings, protocols and practices utilising the resources and knowledge available to them. Furthermore, there are many ways to be Māori and Hera's comment echoes this:

We're not tied by tradition, although we want to have tikanga, we're not tied because we have to use what we can ... And you don't have to prove anything. It's okay to be who you are.

Manu, the supervisor (Case Study Three), makes the point that growing up in a Māori cultural environment, where identity was based on biological kinship groups and community beliefs (May, 2003a), meant she could bring her understandings, learnings and meanings to her practice in the kōhanga.

But what I brought with me ... was what I had grown up with, that intergenerational learning from my ... my grandparents brought me up. Those values are quite respectful of Māori and I will challenge anybody who says otherwise.

Other teachers also brought with them understandings of 'being Māori', which were influenced by both traditional and contemporary concepts, relationships of multiple realities. They also had a range of experiences of working in kōhanga reo. There was a strong sense of 'being
Māori' as a lived reality within the kōhanga and the lives of the whānau.

So we actually started exploring ... I suppose it constituted and reaffirmed that what I was doing as a teacher ... in total immersion Māori in Kōhanga Reo (Manu).

Although teachers felt confident about the opportunity to explore and develop understandings of kaupapa Māori assessment, presenting these understandings to others was daunting. The question was: 'would others see the assessments, as Māori?' These concerns are reflected in Manu's comments.

It was a bit scary at the beginning thinking that people will say, 'Oh what does this girl know? (Manu)'.

This prompted reflection on identity and rights, for example, identity as Māori and rights to reflect 'being Māori' in one's own way. Strength came from Manu's background and her reflections on her right to express who she was in her own way. Her whakapapa made her Māori. This clarity was fundamental to the development thinking and understandings of being Māori as it provided strength, security and freedom. There was a sense that what was being developed in the research project would provide the basis for future development in supporting a strong 'Māori identity' in children. Furthermore, they did not have to adhere to strict definitions of what that might look like. In fact, there was a sense within the project that identity is derived from a multiplicity of sources including contemporary and historical ways of being. This was very powerful and liberating.

... I think that the good thing is that our struggling... will have something, hopefully, something to support them [children] for the future ... and not only that, but it's alright to be who you are (Manu).

\section{Conclusion}

Colonisation, assimilation, land loss, language loss and urbanisation have all worked to transform concepts of Māori identity. This has created a challenge for Māori, about how to maintain a cultural identity within a constantly changing contemporary environment in which Māori identity is marked by multiple sites of belonging and identity and encompass both historical and contemporary identity elements. Geijsel and Meijers (2005) describe this situation as 'the ever-changing configuration of interpretations that individuals attach to themselves, as related to the activities they participate in'. In other words, identity is constructed through the use of 'culturally available building materials' (p. 423). In contemporary urban early childhood contexts, the available identity building materials are derived from multiple sources including contemporary and historical ways of being and sites of belonging. 
For the services in the study, the work involved the development of what Maaka and Fleras, (2005, p. 66) describe as an 'inclusive supra-Māori identity' which encompasses the multiple identities and realities, that exist within modern settings, drawing on, recognising and accommodating the multiple and ever changing realities and Māori identities. McIntosh (2005) makes the point that Māori, as a people, have never stopped being Māori, rather it is what counts as being Māori which has always been contested. A number of questions are posed in Te Whatu Pōkeka (Ministry of Education, 2009, p. 50) that, although intended for children, have resonance and relevance for teachers and their journeys.

Ko wai koe? Nā wai koe? I ahu mai koe i hea?

Who are you? From whom are you? Where have you come from? I am Māori, a descendant of people who came to Aotearoa from Rangiātea, a place located in the spiritual world of Hawaiiki.

\section{References}

Barcham, M. (1998). The challenge of urban Māori: Reconciling conceptions of indigeneity and social change. Asia Pacific Viewpoint, 39(3), 303-314.

Barlow, C. (1991). Tikanga whakaaro: Key concepts in Māori culture. Auckland, New Zealand: Oxford University Press.

Belich, J. (2001). Foreword. In J. Simon \& L. Tuhiwai Smith (Eds.), A civilising mission? Perceptions and representations of the New Zealand native schools system (p. 209). Auckland, New Zealand: Auckland University Press.

Berryman, M. (2008). Repositioning within indigenous discourses of transformation and self-determination. Unpublished Doctoral thesis, University of Waikato, Hamilton, New Zealand. Retrieved July 6, 2011 from http://waikato.researchgateway.ac.nz/.

Bishop, R. (1998). Freeing ourselves from neo-colonial domination in research: A Māori approach to creating knowledge. Qualitative Studies in Education, 11(2), 199219.

Bishop, R. (2005). Freeing ourselves from neocolonial domination in research: A Kaupapa Māori approach to creating knowledge. In N. Denzin \& Y. Lincoln (Eds.), Handbook of qualitative research (pp. $\mathrm{xx}-\mathrm{xx}$ ). Thousand Oaks, California: Sage Publications.

Bishop, R., \& Glynn, T. (1999). Culture counts: Changing power relations in education. Palmerston North, New Zealand: Dunmore Press.

Boyes, S. (2006). Mai i ngā ao e rua - from two worlds: An investigation into the attitudes towards half castes in New Zealand. Unpublished honours dissertation, University of Otago, Dunedin.

Cheung, M. (2008). The reductionist - holistic worldview dilemma. MAI Review, 2008, 3, Research Note 5.

Consedine, R., \& Consedine, J. (2005). Healing our history: The challenge of the treaty of waitangi. Auckland: Penguin.
Durie, A. (1997). Te aka matua keeping a māori identity. In P. Te Whaaiti, M. McCarthy \& A. Durie (Eds.), Mai I rangiatea: Wellbeing and development (pp. 142-162). Auckland: Auckland University Press, Bridget Williams Press.

Durie, M. (1998). Te mana, te kawanatanga: The politics of Māori self-determination. Auckland, New Zealand: Oxford University Press.

Education Review Office. (2010). Promoting success for Māori Students; Schools' Progress, June 2010, Wellington.

Gee, J. (2000). Identity as an analytic lens for research in education. Review of Research in Education, 25, 99-125.

Geijsel, F., \& Meijers, F. (2005.) Identity learning: The core process of educational change. Educational Studies, 31(4), 419-430.

Hohepa, P. (1978). Māori and Pākehā: The one-people myth. In M. King (Ed.), Tihe mauri ora aspects of Māoritanga (pp. 98-111). Wellington, New Zealand: Methuen.

Hokowhitu, B. (2004). Te taminga o te Matauranga: Colonisation in education. In T.M. Ka'ai, J.C. Moorfield, M.P.J. Reilly \& S. Mosley (Eds.), Ki Te Whaiao - An introduction to Māori culture and society (pp. 190-200), Auckland: Pearson Education New Zealand.

Hunt, A.M., \& Macfarlane, A.H. (2011). Building cultural consciousness into teacher professional development. In P. Whitinui (Ed.), Kia tangi te titi: Permission to speak. Successful schooling for Mäori students in the 21st century: Issues, challenges and alternatives (pp. 58-79). Wellington: NZCER.

Irwin, K. (1990). The politics of kohanga reo. In S. Middleton, J. Codd, \& A. Jones (Eds.), New Zealand education policy: Critical perspectives (pp. 110-120). Wellington, New Zealand: Allen and Unwin.

Lave, J., \& Wenger, E. (1991). Situated learning: Legitimate peripheral participation. Cambridge: Cambridge University Press.

Love, C. (2004). Extensions on Te Wheke. Wellington: Open Polytechnic of New Zealand.

Maaka, R., \& Fleras, A. (2005). The politics of indigeneity: Challenging the state in Canada and Aotearoa New Zealand. Dunedin: University of Otago Press.

Mahuika, R. (2008). Kaupapa Māori is critical and anticolonial. Mai Review, 3, 1-16. Retrieved September 29, 2011 from: http://www.review.mai.ac.nz.

Marriot, L., \& Sim, D., (2014). Indicators of inequality for Māori and pacific people. Working papers in public finance, Victoria Business School, University. Wellington.

May, H. (2003a). School beginnings: A history of early years schooling. Case study one. Mission infant schools for Māori children, 1830-40s. Research and Policy Series, No.1. Institute for Early Childhood Studies, Victoria University, Wellington.

May, S. (2003b). Rearticulating the case for minority language rights. Current Issues in Language Planning, 4(2), 95125. 
May, H. (2005). School beginnings. A 19th century colonial story. Wellington, New Zealand: NZCER Press.

May, H., Kaur, B., \& Prochner, L. (Eds.) (2006). Reconceptualizing early childhood education: Research, theory and practice. Proceedings of 14th Conference: Rotorua, New Zealand, Nov. 30th-Dec 4th, 2006.

McIntosh, T. (2005). Māori identities: Fixed, fluid, forced. In J. Liu, T. McCreanor, T. McIntosh, \& T. Teaiwa (Eds.), New Zealand identities: Departures and destinations (pp. 38-51). Wellington, New Zealand: Victoria University Press.

Ministry of Education. (1996). Te Whāriki: He whāriki Mātauranga mō ngā Mokopuna o Aotearoa/Early Childhood Curriculum. Wellington, New Zealand: Learning Media.

Ministry of Education. (2009). Te Whatu Pōkeka: Kaupapa Māori Assessment for Learning: Early Childhood Exemplars. Wellington, New Zealand: Learning Media.

Ministry of Education. (2014). Annual early childhood education (ECE) census summary report 2014. Wellington, New Zealand: Education Counts. Retrieved March 7, 2015 from https://www.educationcounts.govt.nz/statistics/earlychildhood-education/annual-ece-summary-reports.

Ministry of Education. (2015). Early childhood education teacher education qualifications 2016. Wellington, New Zealand: Education.govt.nz. Retrieved March 7, 2015 from http://www.education.govt.nz/early-childhood/ running-an-ece-service/employing-ece-staff/the-numberof-qualified-teachers-your-ece-service-needs/.

Mutu, M. (1998). Barriers to research: The constraints of imposed frameworks. Te Oru Rangahau Māori Research Conference (pp. 51-61). Palmerston North, New Zealand: School of Māori Studies, Massey University.

Parker, M. (2000). Organizational culture and identity. Unity and division at work. London: Sage.

Patterson, J. (1992). Exploring Māori values. Palmerston North, New Zealand: Dunmore Press.

Pihama, L. (1996). Policy construction: In whose interest? A critical analysis of parents as first teachers in relation to Māori education. Social Policy Journal of New Zealand, 7, $108-127$.

Pihama, L., Smith, K., Taki, M., \& Lee, J. (2004). A literature review on kaupapa māori and māori education pedagogy. Prepared for ITP New Zealand by The International Research Institute for Māori and Indigenous Education (IRI). Retrieved May 12, 2015 from
http://elearning.itpnz.ac.nz/files/IRI_Final_Report_ Literature_Review_on_Kaupapa_Māori.pdf.

Raerino, K. (2007). He tirohanga a Ngāti Awa uri taone mo ngā ahuatanga Māori An urban Ngāti Awa perspective on identity and culture. Unpublished master's thesis, Auckland University of Technology, Auckland, New Zealand.

Rameka, L. (2012). Te Whatu Kākahu-Assessment in Kaupapa (Philosophy) Māori Early Childhood Practice. Unpublished doctoral thesis, Waikato University, Hamilton, New Zealand.

Rangihau, J. (1975). Being Maori. In M. King (Ed.), Te Ao Hurihuri: The World Moves On-Aspects of Maoritanga (pp. 167-175). Wellington, New Zealand: Hicks Smith and Sons Ltd.

Reedy, T. (2003). Toku rangitiratanga na te mana-matauranga "Knowledge and power set me free... ". In J. Nuttall (Ed.), Weaving Te Whariki (pp. 51-77). Wellington: New Zealand Council for Educational Research.

Te Ara - The Encyclopedia of New Zealand (nd). Retrieved September 27, 2015 from http://www.teara.govt.nz/en.

Te Rito, S. (2007). Whakapapa: A framework for understanding identity. MAI Review, 2, Article 2. Retrieved February 16, 2011 from http://www.review.mai.ac.nz.

Tisdell, E. (2001). Spirituality and emancipatory adult education in women adult educators for social change. Adult Education Quarterly, 50(4), 308-333.

Walker, R. (1989). Maori identity. In D. Novitz and B. Willmott (Eds.), Culture and Identity in New Zealand (pp. 35-52). Wellington: Government Printer.

Walker, R. (1993, August). A paradigm of the MāoriView of reality. Paper presented to the David Nichol Seminar IX, Voyages and Beaches: Discovery and the Pacific 17001840, Auckland.

Webber, B. (1996). He paepae körero, research perspectives in Mäori education. Wellington: NZCER.

Webber, M. (2008). Walking the space between: Identity and Māori/Pākehā. Wellington, New Zealand: New Zealand Council for Educational Research.

Whitt, L., Roberts, M., Norman, M.W., \& Grieves, V. (2003.) Indigenous perspectives. In D. Jamieson (Ed.), A companion to environmental philosophy (pp. 3-20). Malden, Massachusetts: Blackwell.

Williams, J. (2004). Paptuanuku - attitudes to land. In T.M. Ka'ai, J.C. Moorfield, M.P.J. Reilly, \& S. Mosley (Eds.), Ki Te Whaiao - an introduction to Māori culture and society (pp. 50-60). Auckland, New Zealand: Pearson Education. 


\section{About the Author}

Lesley Rameka is a Senior Lecturer at the Faculty of Education, University of Waikato in Hamilton, New Zealand where she teaches in the early childhood and Māori education programmes. Lesley's research interests include Māori early childhood education, Kaupapa Māori Assessment in early childhood, curriculum development in Māori early childhood services and Māori pedagogies. 